\title{
The Impact of Corporate Governance on Stock Price and Trade Volume
}

\author{
Wafaa Salah Mohamed (Corresponding author) \\ Accounting Department, British University \\ El Sherouk City, Cairo, Egypt \\ Wafaa.salah@bue.edu.eg
}

May M. Elewa

Accounting Department, Six of October University

October 6 City, Cairo, Egypt

Received: July 02, 2016 Accepted: July 28, 2016 Published: August 04, 2016

doi:10.5296/ijafr.v6i2.9757 URL: http://dx.doi.org/10.5296/ijafr.v6i2.9757

\begin{abstract}
The purpose of this paper is to investigate whether corporate governance is associated with stock prices and trade volume for 62 publicly traded firms on the Egyptian Stock Exchange during 2007-2014. The authors hypothesize that firms with strong corporate governance have a significant impact on stock prices and trade volume. To examine the associations, a multiple regression analysis is used. Consistent with the first hypothesis, this study finds firms with strong corporate governance have a significant impact on stock prices while has no significant impact on trade volume. Findings indicate that quality of corporate governance can affect firms' stock price while trading volume is not affected by the strength of corporate governance. The results suggest that Egyptian firms should improve their corporate governance as it has a significant effect on firms' value. Also, providing diverse sources of financial information other than the financial statements and to ensure the presence of highquality financial reporting and strong investor protection. This study is carried on nonfinancial firms only. This research is important to regulators and standard setters as it shows the information that affects investors' decisions and the importance of its disclosure. It pays attention of standard setters for setting a corporate governance framework for improving the level of disclosures of publicly traded firms in Egypt.
\end{abstract}

Keywords: Corporate governance, Trade volume, Stock price, Egypt 


\section{Introduction}

In the past few years, corporate governance has received considerable attention especially after corporate scandals and crises. After the financial collapses of major U.S. companies in 2002, the Sarbanes-Oxley Act were issued, which focused on the role of corporate governance in the elimination of financial and administrative corruption faced by many companies. Corporate governance plays an important role in the stability of financial markets, and the increase in the competitiveness of public shareholding companies. The audit process assesses the probability of material misstatements and reduces the possibility of undetected misstatement to an appropriate assurance level(Watts and Zimmerman 1990). The stock prices in the financial market are characterized by fluctuations. Thus, an appropriate model to explain these fluctuations is needed. This study focuses on investigating the association between corporate governance with stock prices and trade volume in the emerging Egyptian business environment.

Corporate governance can be defined as "the set of rules and incentives by which the management of a company is directed and controlled in order to maximize the profitability and long-term value of the firm for shareholders"(Abdel Shahid 2001). Corporate governance includes financial and non-financial disclosures to increase transparency for stakeholders especially stockholders. It represents the checks and balances incorporated in the system to avoid power misuse. This power may exist in the hands of a company's Chief Executive Officer if there are many owners, or it may be in the hands of one/ a group of shareholders if the company is family owned. Corporate governance indicates how management applies accountability towards shareholders. This implies that the employed corporate systems are designed to keep shareholders totally aware of a firm's financial performance and potentials. Corporate governance is also about making timely and voluntary disclosure regarding events and factors that may affect the interests of shareholders. Corporate governance addresses the agency problems that are induced by the separation of ownership and control in the modern corporation. It can force the managers to disclose important information to reduce information asymmetry between the managers and shareholders (Siagian, Siregar et al. 2013). In this study, it is hypothesized that firms with strong corporate governance have a significant impact on stock prices and trade volume.

Corporate governance has been a topic of research for a long time in the Anglo-Saxon literature. However, there is a shortage of literature that focus on the different factors affecting the firm stock prices and their trade volume in the emerging capital market. This study focuses on studying the emerging Egyptian market for a number of reasons. First, Egypt is located in the Middle East which is currently a politically troubled and unstable region. Despite this instability, Egypt has rapid economic growth compared with other emerging economies (Barako, Hancock et al. 2006, Elsayed and Hoque 2010). According to Barako, Hancock et al. (2006), Egypt has taken major steps in economic reform, improving the investment climate and attracting local, regional and foreign direct investments. Egypt is a developing nation at the beginning of its transition to a market economy. It is applying a privatization program to a large number of its public firms which makes Egypt a relatively attractive market that continues to grow fast. Second, Egypt is still new to the concept of 


\section{Mll Macrothink}

International Journal of Accounting and Financial Reporting

ISSN 2162-3082 2016, Vol. 6, No. 2

corporate governance as those who are responsible for implementing the system are still few in number. According to Kamel Saleh, managing partner at Deloitte Consulting, "Most of the listed companies are either multinationals coming with their own [governance] systems or family businesses that need a transition period to make the system more powerful than individuals"(HAFEZ 2010)

Third, this study is related to the Stock prices. In the Egyptian stock market, stock prices are less informative about the future value of the firm than its accounting information. However, the general notion holds that information is reflected in the change of current stock prices. The Egyptian Stock Exchange EGX is considered one of the oldest stock exchanges that date back to 1882. It kept growing until it was ranked the fifth most active market in the world in the 1950s (ACCE 1995). As discussed by (HassabElnaby, Epps et al. 2003), the energetic growth of the Egyptian accounting system is mainly derived from the level of the economy and the political environment. Salama (2009), added that there has been a growing public and media awareness of the role of corporations in the Egyptian society. Finally, Egypt is a code law country where accounting standards are established and enforced by the government. The financial system of Egypt remains bank-oriented with a small number of banks providing the primary part of the firm financing. There is a weak level of investor protection; high conformity between financial reporting and taxation. In addition, Egypt tends to rank lower than developed markets in terms of the strength of their regulatory environments.

The studies of (Abd-Elsalam and Weetman 2003, Dahawy 2008, Samaha and Stapleton 2008) agree that the Egyptian Capital Market Authority ECMA does not have an effective mechanism for monitoring compliance with IFRS or for punishing registrants for violation; no adequate regulatory mechanisms exist for imposing sanctions on audit firms who fail to comply with IFRS . The studies of (Ball, Robin et al. 2003, Leuz, Nanda et al. 2003, Burgstahler, Hail et al. 2006, Bushman and Piotroski 2006, Daske, Hail et al. 2013) suggests that these institutional structures of code law countries, like Egypt, give preparers incentive to issue low-quality financial reports despite the mandating adoption of high-quality accounting standards international financial reporting standards IFRS. Thus, the legal system can be considered as an important factor in the development of the codes of good governance. In Egypt, the Government, through the Ministry of Economy and the Stock Exchange can play a crucial role in the development of a Corporate Governance Code(Abdel Shahid 2001). Hence, more corporate governance studies are still needed to be conducted in the Egyptian environment for guiding policy makers, regulators, stakeholders, and firms. This study aims at providing an empirical answer to the following question: are firms strong corporate governance have a significant impact on firm stock prices and trade volume? The rest of the paper is organized as follows. The next section discusses the literature review and highlights the theoretical background. The third section provides the hypotheses and describes the data set and variables. The fourth section shows the empirical results and research findings and finally the conclusion. 


\section{Macrothink \\ International Journal of Accounting and Financial Reporting \\ ISSN 2162-3082 \\ 2016, Vol. 6, No. 2}

\section{Literature Review and Hypotheses Development}

\subsection{Corporate Governance}

Academics try to investigate the reasons behind adopting strong corporate governance mechanism. The most widely agreed upon reasons are lower cost of capital, better performance, and more favorable treatment of all stakeholders. The recent financial crisis has showed the importance of corporate governance and how failures in maintaining wellgoverned firms can adversely affect whole economies. These developments have made the monitoring of the use of capital more complex in many ways, enhancing the need for good corporate governance. According to Triole (2001), the main purpose of corporate governance is to ensure the society that large corporations are managed properly so investors and lenders can be sure that their funds are put in the right place. This study confirms that corporate governance protects a company's stakeholders against corruption and mismanagement through promoting essential values of the market economy in democratic societies. Similarly, Claessens and Yurtoglu (2013) define corporate governance as a set of mechanisms through which firms operate when management and ownership are separated. They added that the objective of a strong corporate governance framework is to maximize the contribution of firms to the well-beings of the economy which include all stakeholders.

Dahawy (2008) reports that corporate governance can be very useful to developing countries such as Egypt. Corporate governance can help these countries achieve higher levels of economic growth rates, confidence in the national economy, and the ability to mobilize savings. Meanwhile, corporate governance can play a major role in raising investment rates, and protecting the rights of the minority shareholders or small investors. In addition, corporate governance enhances the growth of private companies by sustaining their competitive abilities, helping them secure their financial resources, fostering their profits, and improve their job creating capacities. Several studies show that strong corporate governance mechanism affects the access, the amount of external financing, cost of capital and firm valuation. Creditors are reluctant to provide financing to weaker corporate governance settings or charge higher rates to get an adequate rate of return (Claessens, Djankov et al. 2000, Lins 2003, Jackson and Roe 2009).

Internal controls refer to a company's monitoring mechanisms. In the principal-agent relationship, the principal selects these mechanisms. Meanwhile, the agent chooses the bonding mechanisms at some cost. The monitoring mechanisms are related to the characteristics of the Board of Directors (BOD), procedures of internal control, management share of a company's ownership, managerial compensation, and the change in management. BOD characteristics and internal control procedures are considered overseers of the financial reporting system that restrain a manager's power to manage earnings. On the other hand, management ownership of the company's shares and managerial compensation enhance earnings management. As for internal controls, they are expected to affect earnings management. 


\subsection{The impact of corporate governance on stock returns}

Recently, how corporate governance affect firms are receiving more attention(Claessens and Yurtoglu 2013). Bauer and Guenster (2003), examine the impact of corporate governance on stock returns, firm value and operating performance for firms incorporated in member states of the European Monetary Union (EMU). The study uses Deminor Corporate governance ratings to compare the stock returns of well-governed firms to stock returns of poorly governed firms. The sample of the study covered five years from 1997 to 2002 and included firms of Euro zone included in the FTSE Euro top 300 index. The results show that investors perceive a higher value for well-governed firms. The result of this study is compatible with the findings of (Gompers, Ishii et al. (2001), Drobetz, Schillhofer et al. (2004)) where they constructed a Corporate Governance Index to proxy for the level of shareholder rights and find firms with stronger shareholder rights are more profitable, have higher sales growth, lower capital expenditures, and made fewer corporate acquisitions than firms with weak shareholder rights.

Malik (2012) examines the relationship between corporate governance score and stock prices of firms listed on the Karachi Stock Exchange KSE30 Index . The study focuses on the KSE 30 index firms during the period 2009 - 2010. The study uses the corporate governance score as an independent variable, and firm's share price as a dependent variable. Findings imply that well-governed firms have higher stock prices and the opposite is true. This happens because better-managed firms are expected to perform better and consequently the stock prices are expected to increase. In a related study, (Chahine, Zeidan et al. (2012)) examine the effect of corporate governance on market reaction around of a share repurchase announcement. They found that firms that are transparent and well-governed have a higher market reaction to announcements of stock repurchases. In addition, they find evidence of a cumulative abnormal return of well-governed firms that is significantly higher than badgoverned firms. They suggest that this result for well-governed firms could be an indicator of undervaluation and for poor- governed firms could be an indicator of mitigating agency conflicts more than signaling. They suggest further investigation in this area.

Uwuigbe (2013) examines the relationship between share price and corporate governance practices. The firm audit committee and the firm ownership structure represent the corporate governance practice. The study uses a sample of 30 firms listed on the Nigerian Stock Exchange. The research applies the Regression and Correlation Analysis methods. Findings indicate: (a) there is a negative relation of firm ownership structure on firm share prices and (b) there is a positive relation of firm audit committee to firm share prices. Poor corporate governance of firms can adversely affect the economy in both developed and developing countries. During the East Asian crisis in 1997, poor corporate governance was main factor for increasing the decline of stock market. In addition, some firms collapse as Enron due to fraud and false reports. This led to crises and collapse of stock market which affect the economic growth(Claessens and Yurtoglu 2013).Similarly, According to Cornett, McNutt et al. (2009), during the crisis, firms with strong corporate governance tend to have higher rates of return. 


\section{Mll Macrothink}

International Journal of Accounting and Financial Reporting ISSN 2162-3082 2016, Vol. 6, No. 2

The aim of Talal and Mostafa (2014) study is to see if the corporate governance principles are applied in the Amman business environment and to evaluate performance of firms applying these principles. A questionnaire was passed out, collected, and analyzed from 140 professionals (general directors, deputies, managers, administrators, finance) throughout 70 firms listed in the Amman Stock Exchange. Findings imply that (a)there is an understanding of the principles of corporate governance and an awareness of its importance (b)firms listed in the Amman Stock Exchange apply the principles of corporate governance, and (c) a significant increase in stock prices is noticed in firms that apply the corporate governance principle .The contribution of the Talal and Mostafa (2014) study is that (a) it provides an understanding of the principle of corporate governance and (b) it provides awareness of the importance of the application of these principles, and (c) it indicates the significant effect of the application of these principle on the value of the firm stock prices. The recommendations of this study are: a) to provide an understanding of the corporate governance principles for managers of listed firms, b) to apply the principles of corporate governance, c) the continuous adjustment of the corporate governance principle according to the ongoing change of the business environment, d) to spread awareness to managers in industrial firms of the effect of applying principles of corporate governance to the value of firms' stock prices, and e) continuous development of the methods used to apply the principles of corporate governance. Based on the discussion above, our testable hypotheses are as follows:H1: firms with strong corporate governance have a significant impact on stock prices. $\mathrm{H} 2$ : firms with strong corporate governance have a significant impact on trade volume.

\section{Sample Design and Data Description}

\subsection{Sample and Data}

This part describes the population and identifies the set criteria used to select the firms tested. The 62 selected firms are regrouped into four new groups (Basic Resources, Chemicals, Construction and Materials, Industrial Goods and Services and Automobiles), (Real Estate, Travel \& Leisure), (Financial Services excluding Banks) and (Food and Beverage). The data sources are listed. The statistics package used is indicated. The criteria for the data selection from the data collected are set. The dependent and independent variables were chosen for the study according to a pilot study made and literature related to the topic. Finally, the presentation for statistic results of the research hypotheses is made. Multiple regression analysis for each hypothesis is used with the following procedures:

- Variance inflation factor (VIF) was calculated for each independent variable to test the assumption of "no multicollinearity", and variables with VIF greater than 10 were excluded from the analysis.

- Breusch-Godfrey Serial Correlation test was conducted to test the assumption of "no autocorrelation".

- White test was conducted to test the assumption of "homoscedasticity".

If either hetroscedasticity or autocorrelation is present, standard errors of the estimates are corrected by the Newey-West HAC (Hetroscedasticity and Autocorrelation Consistent) 


\section{1l Macrothink}

International Journal of Accounting and Financial Reporting

ISSN 2162-3082

2016, Vol. 6, No. 2

procedure. This study uses publicly traded firms on the Egyptian Stock Exchange during the period 2007 to 2014 that are equivalent to a total of 496 firm year observations. To build the database for this research, several sources have been relied on to collect the annual reports used; the main source was "Egypt for Information Dissemination - EGID" which is a fully owned subsidiary of the Egyptian Stock Exchange (EGX) and is the main provider of information for the Egyptian Stock Market. Other sources of information for this research was obtained from the web page of each of the selected companies (if available); and other specialized websites which include data bases of listed companies in the EGX (for example, www.mistnews.com; and www.mubasher. info).

Table 1 Firms listed in nonfinancial sectors in the Egyptian Stock Exchange

\begin{tabular}{|c|c|c|c|}
\hline & Sector & Number & $\%$ \\
\hline 1 & Basic Resources & 9 & 4.5 \\
\hline 2 & Chemicals & 7 & 3.5 \\
\hline 3 & Construction and Material & 24 & 12 \\
\hline 4 & Financial Services Excluding Banks & 27 & 13.5 \\
\hline 5 & Food and Beverage & 27 & 13.5 \\
\hline 6 & Health Care Pharmaceuticals & 16 & 8 \\
\hline 7 & Industrial Goods and Services and Automobiles & 17 & 8.5 \\
\hline 8 & Oil and Gas & 3 & 1.5 \\
\hline 9 & Personal and Household Products & 10 & 5 \\
\hline 10 & Real Estate & 30 & 15 \\
\hline 11 & Media & 1 & 0.5 \\
\hline 12 & Retail & 4 & 2 \\
\hline 13 & Technology & 3 & 1.5 \\
\hline 14 & Telecommunications & 4 & 2 \\
\hline
\end{tabular}




\begin{tabular}{|l|l|l|l|}
\hline 15 & Travel \& Leisure & 17 & 8.5 \\
\hline 16 & Utilities & 1 & 0.5 \\
\hline & Total & 200 & \\
\hline
\end{tabular}

The Egyptian stock exchange consists of financial and nonfinancial institutions. It is inferred from the above table that the non-financial institutions listed on the EGX are divided into 16 sectors with a total number of 200 institutions.

Table 2 Firms listed in nonfinancial sectors in the Egyptian Stock Exchange that meet the established criteria

\begin{tabular}{|l|l|l|l|}
\hline & Sector & Number & $\%$ \\
\hline 1 & Basic Resources & 9 & 4.5 \\
\hline 2 & Chemicals & 7 & 3.5 \\
\hline 3 & Construction and Material & 24 & 12 \\
\hline 4 & Financial Services Excluding Banks & 27 & 13.5 \\
\hline 5 & Food and Beverage & 27 & 13.5 \\
\hline 6 & Industrial Goods and Services and Automobiles & 17 & 8.5 \\
\hline 7 & Real Estate & 30 & 15 \\
\hline 8 & Travel \& Leisure & 17 & 8.5 \\
\hline & Total & 158 & \\
\hline
\end{tabular}

Table 2 include the Firms listed in nonfinancial sectors in the Egyptian Stock Exchange excluding (Health Care Pharmaceuticals, Personal and Household Products, Media, Retail, Technology, Telecommunications, utility, oil and gas) that don't meet the established criteria. This number is broken down even more according to established criteria by the researcher: the firm listing on the EGX100, the firm operates in cash, the annual report of the firm dates from $1 / 1$ to $31 / 12$, there is no missing data, and the firm is not disqualified at any time during the research period. The firms with financial annual reports dating from 1/1 to 31/12 are chosen for the study because they are greater in number than the firms with financial annual 
reports dating from $30 / 6$ to $31 / 12$.

The missing data might be because of the following reasons as identified by their disclosure: a) the firm started its activity or registered in the EGX any time after 2007 (keeping in mind that the research study time span is 2007-2014), b) the firm may have faced some structural internal transitions as downsizing or change in the board of directors, c) the firm may have faced external transitions as merging, acquisition, expansion or split up, d) the firm may have changed external auditors, or the firm may have been dramatically affected by external catastrophe like war or revolution due to its inability to continue operating in this circumstance.

When running the 200 firms across the established criteria 62 firms were valid. This number is considered reasonable to use since the minimum number of acceptable statistical units is 30. These 62 firms were regrouped to 4 groups according to their relation with each other. This relation was determined according to the company description and nature found in the disclosure. These 4 groups are (Basic Resources, Chemicals, Construction and Materials, Industrial Goods and Services and Automobiles), (Real Estate, Travel \& Leisure), (Financial Services excluding Banks) and (Food and Beverage). The (Health Care Pharmaceuticals, Personal and Household Products, Media, Retail, Technology, Telecommunications, utility, oil and gas) sectors are not included in the new groups because no institutions from these sectors are included in the study because they don't meet the established criteria. Thus, the 62 firms used are characterized by the following: non-financial institutions, listed on the EXG 100 , operates in cash, the annual report dates from $1 / 1$ to $31 / 12$, there is no missing data, and the firm is not disqualified at any time during the research period.

Table 3 Regrouping of the nonfinancial sectors according to the established criteria

\begin{tabular}{|l|l|l|l|l|}
\hline \multirow{2}{*}{ Group } & Sector & Number & $\%$ & Total \\
\hline \multirow{2}{*}{ Group 1 } & Basic Resources & 2 & 10.5 & \multirow{2}{*}{19} \\
\cline { 2 - 4 } & Chemicals & 2 & \multirow{2}{*}{10.5} & \multirow{2}{*}{52.6} \\
\cline { 2 - 4 } & Construction and Materials & 10 & \multirow{2}{*}{26.3} & \\
\cline { 2 - 4 } & Industrial Goods and Services and Automobiles & 5 & \multirow{2}{*}{66.7} & \multirow{2}{*}{21} \\
\hline \multirow{2}{*}{ Group 2 } & Real Estate & 14 & 33.3 & \\
\cline { 2 - 4 } & Travel \& Leisure & 7 & 100 & \multirow{2}{*}{14} \\
\hline
\end{tabular}




\begin{tabular}{|l|l|l|l|l|}
\hline Group 4 & Food and Beverage & 8 & 100 & 8 \\
\hline & Total & 62 & & 62 \\
\hline
\end{tabular}

Table 3 include the regrouping of the nonfinancial sectors according to the established criteria excluding (Health Care Pharmaceuticals, Personal and Household Products, Media, Retail, Technology, Telecommunications, utility, oil and gas) and the number of firms. From the above table the following is inferred:

When regrouping the 16 sectors, 8 sectors (Health Care Pharmaceuticals, Personal and Household Products, Media, Retail, Technology, Telecommunications, utility, oil and gas) were excluded. Accordingly,

Group 1 (Basic Resources, Chemicals, Construction and Materials, Industrial Goods and Services and Automobiles) represents $36 \%$ of the grand total. Group 1 consists of 19 firms. These institutions are broken up to 2 basic resources, 2 chemicals, 10 construction and materials, 5 Industrial Goods and Services and Automobiles. 2 out of 9 basic resources institutions represent $22 \%$ of the total basic resources sector. 2 out of 7 chemicals institutions represent $29 \%$ of the total chemicals sector.

10 out of 24 construction and material institutions represent $42 \%$ of the total construction and material sector. 5 out of 17 Industrial Goods and Services and Automobiles institutions represent 29\% of the total Industrial Goods and Services and Automobiles sector. 19 out of 57 (Basic Resources, Chemicals, Construction and Materials, Industrial Goods and Services and Automobiles) institutions represent 33\% of the total (Basic Resources, Chemicals, Construction and Materials, Industrial Goods and Services and Automobiles) sector.

Group 2 (Real Estate, Travel \& Leisure) represents $29.7 \%$ of the grand total. Group 2 consists of 21 firms. These firms are broken up to 14 real estate and 7 travel and leisure. 14 out of 30 Real Estate firms represent $47 \%$ of the total Real Estate sector. 7 out of 17 travel and leisure firms represent $41 \%$ of the total travel and leisure sector. 21 out of 47 (Real Estate, Travel \& Leisure) firms represent $45 \%$ of the total (Real Estate, Travel \& Leisure) sector.

Group 3 (Financial Services Excluding Banks) sector represents 17\% of the grand total. Group 3 consists of 14 out of 27 firms that represent 52\% of the total (Financial Services Excluding Banks) sector.

Group 4 (Food and Beverage) sector represents $17 \%$ of the grand total. Group 4 consists of 8 out of 27 firms that represent $30 \%$ of the total (Food and Beverage) sector.

The firms selected; are non-financial firms, are firms listed in the EGX100, are firms that operate in cash, are firms that have annual reports that date from $1 / 1$ to $31 / 12$, have no missing data, and are not disqualified at any time during the research period.

The Share Price is taken as a dependent variable. The share price is calculated by adding up the daily average share prices of the companies under study and dividing the result by the number of days the shares are traded Uwuigbe (2013). The trade volume is used as a 


\section{MlMnstitute ${ }^{\text {Macrothink }}$}

dependent variable as well.

A pilot study was made to specify the independent variables used in the study that were predicted to have a significant impact on the stock prices in the emerging Egyptian capital market. EViews is used to achieve the required statistical analysis. It is a software package that provides tools for data analysis, regression, and forecasting. It is a regression package for econometric analysis. EViews is basically used for the availability of the Newey-West HAC (Hetroscedasticity and Autocorrelation Consistent) procedure which is a corrective procedure for the hetroscedasticity (the changing variance nature of the data) or autocorrelation (the correlation of a time series with its own past and future values) if one or both of these standard errors of the estimates exist. In addition, the availability of more widely used tools for the testing of the assumptions of "no multicollinearity", "no autocorrelation" and "homoscedasticity".

\subsection{Variables}

1- Modified Jones Model (earnings management)

$\mathrm{NDAt}=\alpha 1(1 / \mathrm{At}-1)+\alpha 2(\Delta \mathrm{REVt}-\Delta \mathrm{RECt})+\alpha 3(\mathrm{PPEt})$

- NDAt $=$ non-discretionary accrual in year $\mathrm{t}$

- At- $1=$ total assets at $\mathrm{t}-1$

$-\triangle \mathrm{REV}=$ change in revenue (revenues in year $\mathrm{t}$ less revenues in year $\mathrm{t}-1$ )

$-\triangle \mathrm{REC}=\mathrm{Change}$ in accounts receivable (net receivables in year $\mathrm{t}$ less net receivables in year $\mathrm{t}-1$ )

- PPEt $=$ gross property plant and equipment in year $\mathrm{t}$

$-\alpha 1, \alpha 2, \alpha 3 \quad$ firm specific parameters

2- $\log$ (Nwords) $=$ "Log of" the total number of words in the management discussion(MD) and disclosure(Dis)

The independent variable in this study is Firms corporate governance and measured using the following variables: Big 4, NonBig 4, NonDiscretionary Accruals (NDA), and Word Count. The dependent variable in the first hypothesis is stock price and in the second hypothesis is trade volume.

\section{Empirical Results and Research Findings}

H1. Firms with strong corporate governance have significant impact on stock prices. To test this hypothesis, multiple regression analysis was used with the following procedures:

- Variance inflation factor (VIF) was calculated for each independent variable to test the assumption of "no multicollinearity", and variables with VIF greater than 10 were excluded from the analysis.

- Breusch-Godfrey Serial Correlation test was conducted to test the assumption of "no 
autocorrelation".

- White test was conducted to test the assumption of "homoscedasticity".

- If either hetroscedasticity or autocorrelation is present, standard errors of the estimates are corrected by the Newey-West HAC procedure (Hetroscedasticity and Autocorrelation Consistent). The table below shows the results of the analysis.

Table 4. The relation of corporate governance with stock prices

\begin{tabular}{|c|c|c|c|c|}
\hline \multirow[t]{2}{*}{ Independent variable } & \multirow[t]{2}{*}{$\mathbf{B}$} & \multicolumn{2}{|l|}{ T-Test } & \multirow[t]{2}{*}{ VIF } \\
\hline & & Value & Sig. & \\
\hline Constant & 21.45773 & 1.230705 & 0.2191 & NA \\
\hline BIG4 & -22.62863 & -1.638992 & 0.1019 & 3.216638 \\
\hline NONBIG4 & -33.94510 & -2.445429 & 0.0148 & 3.006729 \\
\hline NDA & $6.68 \mathrm{E}-08$ & 3.577921 & 0.0004 & 1.027755 \\
\hline N_WORDS & 0.009785 & 0.962660 & 0.3362 & 1.254460 \\
\hline F-statistic & 22.31774 & & & \\
\hline Sig. & 0.000000 & & & \\
\hline $\mathrm{R}^{2}$ & 0.163419 & & & \\
\hline $\begin{array}{l}\text { Breusch-Godfrey Serial } \\
\text { Correlation test (Sig.) }\end{array}$ & 0.0000 & & & \\
\hline White test (Sig.) & 0.0000 & & & \\
\hline
\end{tabular}

No variables were excluded from the analysis. The Hetroscedasticity and Autocorrelation Consistent procedure was used to correct the standard errors for hetroscedasticity and autocorrelation. The value of coefficient of determination (R2) is 0.163419 , i.e. the independent variables collectively explain $16.3 \%$ of the variance in the dependent variable (stock price). The results indicate that the overall regression model is significant $(\mathrm{F}=$ 22.31774, P-value < 0.05). T-Test showed that Non Big 4 auditing firms and Non Discretional Accruals have significant effect on the dependent variable (stock price) and the relationship is negative for the Non Big 4 auditing firms and positive for the Non Discretional Accruals. The 


\section{MlMacrothink}

International Journal of Accounting and Financial Reporting

ISSN 2162-3082

2016, Vol. 6, No. 2

other independent variables have no significant effect as indicated from the above table.

Accordingly, $\mathrm{H} 1$ is supported. Firms with strong corporate governance have significant impact on stock prices. According to Triole (2001), the main purpose of corporate governance is to ensure society that large corporations are managed properly so investors and lenders can be sure that their funds are put in the right place. This study confirms that corporate governance protects a company's stakeholders against corruption and mismanagement through promoting essential values of market economy in democratic societies. According to Malik (2012), corporate governance is one of the important determinants of stock price. Walker (2013), undertakes a critical review and analysis of recent and relevant research papers to gain a better understanding of the claim that "improved adoption of corporate governance principles by firms positively affects equity value". The findings of this study suggest that the adoption of corporate governance principles increases the value of firm stock prices. The finding of Uwuigbe (2013) suggests that ownership structure have a negative association with share price, whereas the audit committee is positively related to share price. The study recommends that board members' shareholding should be regulated to ensure an optimal share price disposition.

H2. Firms with strong corporate governance have high trade volume. To test this hypothesis, multiple regression analysis was used as was done for the stock price. The following procedures were done:

- Variance inflation factor (VIF) was calculated for independent variable to test the assumption of "no multicollinearity", and variables with VIF greater than 10 were excluded from the analysis.

- Breusch-Godfrey Serial Correlation test was conducted to test the assumption of "no autocorrelation".

- White test was conducted to test the assumption of "homoscedasticity".

- If either hetroscedasticity or autocorrelation is present, standard errors of the estimates are corrected by the Newey-West HAC procedure (Hetroscedasticity and Autocorrelation Consistent).

The table below shows the results of the analysis. It shows the relation of corporate governance with trade volume. It is concluded that no variables were excluded from the analysis. The Hetroscedasticity and Autocorrelation Consistent procedure was used to correct the standard errors for hetroscedasticity and autocorrelation. 


\section{Macrothink \\ International Journal of Accounting and Financial Reporting \\ ISSN 2162-3082 2016, Vol. 6, No. 2}

Table 5. The relation of corporate governance with trade volume

\begin{tabular}{|l|l|l|l|l|}
\hline \multirow{2}{*}{ Independent variable } & \multirow{2}{*}{ B } & \multicolumn{2}{l}{ T-Test } & \multirow{2}{*}{ VIF } \\
\cline { 3 - 5 } & & Value & \multicolumn{1}{l}{ Sig. } & \\
\hline Constant & 1180203. & 4.451127 & 0.0000 & \multirow{2}{*}{ NA } \\
\hline BIG4 & -- & -- & -- & 3.216638 \\
\hline NONBIG4 & -- & -- & -- & 3.006729 \\
\hline NDA & -- & -- & -- & 1.027755 \\
\hline N_WORDS & -- & -- & -- & 1.254460 \\
\hline F-statistic & 0.716823 & & \\
\hline Sig. & 0.580737 & & & \\
\hline R & 0.006235 & & & \\
\hline $\begin{array}{l}\text { Breusch-Godfrey Serial } \\
\text { Correlation test (Sig.) }\end{array}$ & 1.0000 & & & \\
\hline White test (Sig.) & 0.9968 & & & \\
\hline
\end{tabular}

The value of coefficient of determination (R2) is 0.006235 , i.e. the independent variables collectively explain $0.6 \%$ of the variance in the dependent variable. The results indicate that the overall regression model is significant $(\mathrm{F}=0.716823$, P-value $<0.05)$. T-Test showed that none of the variables have a significant effect on the dependent variable (trade volume). Results indicated that this relation was not supported. This indicates that perhaps there is a limited or no link between the trade volume and the corporate governance, despite, stock price and trade volume goes hand in hand in practice. However, literature shows that only stock price is used in statistical analysis without accompanying the trade volume. Example of supporters are Uwuigbe (2013) and Ismail and Elbolok (2011).

Firms with strong corporate governance have high stock price. Non Big 4 auditing firms and Non Discretional Accruals have significant effect on the dependent variable (stock price) and the relationship is negative for the Non Big 4 auditing firms and positive for the Non Discretional Accruals. On the other hand, results indicated that relation was not supported between corporate governance and trade volume. The result of this study is compatible with the findings of Drobetz, Schillhofer et al. (2004) and Page (2009) where firms that 
incorporate the principles of corporate governance is reflected on stock price.

\section{Conclusions}

This study examines the association between corporate governance and firms' stock prices and trade volume in order to assist standard setters in meeting their goal of improving the quality of financial reporting and decision making. The study findings show that good corporate governance leads to higher stock return. The findings differ from those of the previous literatures due to the criteria set for the firms selected and analyzed. Our findings suggest several broader issues. Managers could benefit from knowing that strong corporate governance affect firm value and this encourage them to enhance corporate governance disclosure. In addition, policy maker can help firms improve their performance by establish frameworks for corporate governance disclosure.

Following are the main concluding remarks and proposed recommendations of this paper:

1) The characteristics of the Egyptian practice include: high uncertainty avoidance, large power distance, preference for collectivism, and a masculine attitude that drive accounting values to be uniform; secretive; and conservative. Education awareness and professional training is essential to modify the prevailing characteristics of the Egyptian business environment and accounting system. This can be achieved through different channels mainly the following:

a- Providing outreach programs for financial executives and accounting staff to disseminate knowledge on current developments in accounting and financial reporting standards and practices,

b- Providing continuous training and education programs to enhance the awareness of the Egyptian Accounting Standards' practices,

c- Providing sessions of awareness for the board of directors to stress the importance and benefits of implementing the Egyptian Accounting Standards to their companies, and

d- Conducting continuous reviewing and updating of the accounting curriculum.

2) Stock prices in Egypt are less informative about the future value of the firm than is accounting information. However, the general notion holds that information is reflected in the change in current stock prices. To deal with this issue, the study recommends the following:

a- Providing diverse sources of financial information other than the financial statements,

b- Identifying an alternative other than the stock prices to provide future information about the firm value.

Further examination is required for the Conservatism of income recognition to identify its effect on stock prices and trade volume in the firms operating in the Egyptian business 
environment. Another important related topic for future research is an alternative to stock price. When searching for the factors that impact the quality of earnings and their Earnings per Share (EPS) instead of their stock price. The Earnings per Share (EPS) is more dependable in the Egyptian business environment than the stock price as theoretically indicated.

\section{References}

Abd-Elsalam, O. H. and P. Weetman (2003). "Introducing International Accounting Standards to an emerging capital market: relative familiarity and language effect in Egypt." Journal of International Accounting, Auditing and Taxation 12(1): 63-84.

Abdel Shahid, S. F. (2001). "Corporate Governance is a Global Pursuit: What Could Be Done in Egypt?" Cairo \& Alexandria Stock Exchanges Working Paper(1).

Abd-Elsalam, O. H. and P. Weetman (2003). "Introducing International Accounting Standards to an emerging capital market: relative familiarity and language effect in Egypt." Journal of International Accounting, Auditing and Taxation 12(1): 63-84.

Abdel Shahid, S. F. (2001). "Corporate Governance is a Global Pursuit: What Could Be Done in Egypt?" Cairo \& Alexandria Stock Exchanges Working Paper(1).

ACCE (1995). The Capital Market in Egypt, American Chamber of Commerce in Egypt, Business Service Division Giza.

Ball, R., et al. (2003). "Incentives versus standards: properties of accounting income in four East Asian countries." Journal of Accounting and Economics 36(1): 235-270.

Barako, D. G., et al. (2006). "Factors influencing voluntary corporate disclosure by Kenyan companies." Corporate Governance: An International Review 14(2): 107-125.

Bauer, R. and N. Guenster (2003). "Good corporate governance pays off." Well-governed companies perform better on the stock market. International Association for Business and Society Proceedings: 205-210.

Burgstahler, D. C., et al. (2006). "The importance of reporting incentives: Earnings management in European private and public firms." The accounting review 81(5): 983-1016.

Bushman, R. M. and J. D. Piotroski (2006). "Financial reporting incentives for conservative accounting: The influence of legal and political institutions." Journal of Accounting and Economics 42(1): 107-148.

Chahine, S., et al. (2012). "Corporate governance and the market reaction to stock repurchase announcement." Journal of Management \& Governance 16(4): 707-726.

Claessens, S., et al. (2000). "The separation of ownership and control in East Asian corporations." Journal of financial Economics 58(1): 81-112.

Claessens, S. and B. B. Yurtoglu (2013). "Corporate governance in emerging markets: A 
survey." Emerging markets review 15: 1-33.

Cornett, M. M., et al. (2009). "The financial crisis, internal corporate governance, and the performance of publicly-traded US bank holding companies." Internal Corporate Governance, and the Performance of Publicly-Traded US Bank Holding Companies (January 22, 2009).

Dahawy, K. (2008). Developing nations and corporate governance: The story of Egypt. The International Financial Corporation (IF) The Global Corporate Governance Forum.-2009. Access available from:< http://www. ifc. org/ifcext/cgf. nsf/AttachmentsByTitle/PaperKhaledDahawy/\$ FILE/Dahawy_Kahled4. pdf.>.(accessed on September 24, 2010).

Daske, H., et al. (2013). "Adopting a label: Heterogeneity in the economic consequences around IAS/IFRS adoptions." Journal of Accounting Research 51(3): 495-547.

Drobetz, W., et al. (2004). "Corporate governance and expected stock returns: Evidence from Germany." European financial management 10(2): 267-293.

Elsayed, M. O. and Z. Hoque (2010). "Perceived international environmental factors and corporate voluntary disclosure practices: An empirical study." The British Accounting Review 42(1): 17-35.

Gompers, P. A., et al. (2001). Corporate governance and equity prices, National bureau of economic research.

HAFEZ, T. (2010). "IN DEPTH - CORPORATE GOVERNANCE, ACCOUNTABILITY, TRANSPARENCY PAY OFF." Retrieved 06, 2016, from http://amcham.org.eg/resources_publications/publications/business_monthly/issue.asp?sec=4 $\&$ subsec $=$ CORPORATE $\% 20$ GOVERNANCE\&im $=6 \&$ iy $=2010$.

HassabElnaby, H. R., et al. (2003). "The impact of environmental factors on accounting development: an Egyptian longitudinal study." Critical Perspectives on Accounting 14(3): 273-292.

Ismail, T. H. and R. Elbolok (2011). "Do conditional and unconditional conservatism impact earnings quality and stock prices in Egypt?" Research Journal of Finance and Accounting 2(12): 7-22.

Jackson, H. E. and M. J. Roe (2009). "Public and private enforcement of securities laws: Resource-based evidence." Journal of financial Economics 93(2): 207-238.

Leuz, C., et al. (2003). "Earnings management and investor protection: an international comparison." Journal of financial economics 69(3): 505-527.

Lins, K. V. (2003). "Equity ownership and firm value in emerging markets." Journal of financial and quantitative analysis 38(01): 159-184.

Malik, S. U. (2012). "Relationship between corporate governance score and stock prices: Evidence from KSE-30 index companies." International Journal of Business and Social 


\section{Macrothink \\ International Journal of Accounting and Financial Reporting \\ ISSN 2162-3082 \\ 2016, Vol. 6, No. 2}

Science 3(4).

Page, M. (2009). Corporate governance and corporate performance: UK FTSE 350 Companies, Citeseer.

Salama, A. (2009). Egypt: social responsibility disclosure practices. Global Practices of Corporate Social Responsibility, Springer: 325-342.

Samaha, K. and P. Stapleton (2008). "Compliance with International Accounting Standards in a national context: some empirical evidence from the Cairo and Alexandria Stock Exchanges." Afro-Asian Journal of Finance and Accounting 1(1): 40-66.

Siagian, F., et al. (2013). "Corporate governance, reporting quality, and firm value: evidence from Indonesia." Journal of Accounting in Emerging Economies 3(1): 4-20.

Talal, A. and A. Mostafa (2014). "the role of corporate governance and its impact on the share price of industrial corporations listed on the ASE." European Journal of Accounting Auditing and Finance Research Vol 2: 124-144.

Triole, J. (2001). "Corporate Governance." Economertica 69(1): 1-35.

Uwuigbe, O. R. (2013). "Corporate governance and share price: Evidence from listed firms in Nigeria." African Research Review 7(2): 129-143.

Walker, S. (2013). Corporate Governance: Its effect on Share Price. Manchester: Doctoral Symposium.

Watts, R. L. and J. L. Zimmerman (1990). "Positive accounting theory: a ten year perspective." Accounting review: 131-156.

\section{Copyright Disclaimer}

Copyright for this article is retained by the author(s), with first publication rights granted to the journal.

This is an open-access article distributed under the terms and conditions of the Creative Commons Attribution license (http://creativecommons.org/licenses/by/3.0/). 